"environmental"' growth delay (non-organic failure to thrive). Intellectually they often have depressed intelligence quotients and language disorders. Their behaviour may be bizarre, and their views of themselves are often extremely poor.

There seem to be no specific differences between the behaviour patterns of boys with constitutional delay and growth hormone deficiency. ${ }^{5}$ Age is the most important factor influencing the children's difficulties. As puberty approaches the importance of stature increases, especially among boys. ${ }^{1}$ The growth spurts of peers emphasise height differences, and peer pressures for group identification may be associated with the exclusion of small children. They become isolated but not through general lack of social skills ${ }^{6}$ (except for some girls with Turner's syndrome who may have more difficulty in understanding social cues $\left.^{4}\right)$. At this time small children are most vulnerable, and their academic performance deteriorates before recovering in later adolescence. ${ }^{6}$ Greater attention to physical characteristics coupled with greater attention to internal physical states by those who care for them increases the distress. ${ }^{7}$ Increased self awareness often leads to negative self evaluations.

In our response to small children we need to maximise their resources and maintain expectations that are appropriate for age rather than height. The aim is to foster their autonomy and facilitate a sense of their own capabilities. They must be helped to live with their predicament in a positive manner; they must not be allocated the sick role. This means making demands that stretch their capabilities, which are likely to be commensurate with age rather than height. Psychological investigations may help clarify specific learning difficulties.
Small children may be taught ways of coping with the social pressures of adolescence as puberty approaches. We need to question the value that society places on size rather than to contemplate using growth hormone more. Programmes to reduce bullying ${ }^{8}$ suggest that initiatives directed at social processes in schools may create a better climate for the psychological growth of these children. ${ }^{9}$ Resilience does not lie in avoiding stress but rather in encountering it in a way that allows self confidence and social competence to increase through mastery and appropriate responsibility. ${ }^{10}$

Consultant,

SIMON R WILKINSON

Department of Child Psychiatry,

Ullevål Sykehus,

0407 Oslo 4,

Norway

\footnotetext{
Morrow J. Deviational salience; application to short stature and relation to perception of adolescent boys. Percept Mot Skills 1984;59:623-33.

2 Lerner RM, Korn SJ. The development of body build stereotypes in males. Child Dev 1972;43 908-20.

3 Dorner S, Elton A. Short, taught and vulnerable. Special Education 1973;62:12-6.

4 Skuse D. The psychological consequences of being small. F Child Psychol Psychiatry 1987;28: $641-50$.

Holmes CS, Hayford JT, Thompson RG. Personality and behavior differences in groups of boys with short stature. Children's Health Care 1982;11:61-4.

6 Holmes CS, Karlsson JA, Thompson RG. Social and school competencies in children with shor stature: longitudinal patterns. F Dev Behav Pediatr 1985;6:263-7.

Mechanic D. Adolescent health and illness behavior: review of the literature and a new hypothesis for the study of stress. $\mathcal{F}$ Human Stress 1983;9:4-13.

8 Olweus D, Roland E. Mobbing: bakgrunn og tiltak (Bullying: background factors and approaches). Oslo: Kirke-og Undervisnings Departement, 1983.

9 Olwens D. Schoolyard bullying - grounds for intervention. School Safety 1987 Fall:4-11

10 Rutter M. Resilience in the face of adversity: protective factors and resistance to psychiatric disorder. Br f Psychiatry 1985;147:598-611.
}

\title{
Vascular disease, thrombosis, and recurrent abortion
}

\section{May be linked by antibodies against phospholipids}

In the past few years a clinical syndrome has been defined that links venous thrombosis, recurrent abortion, and unexplained cerebral dysfunction and ischaemic episodes. ${ }^{1-3}$ These clinical observations have been associated with antibodies directed against phospholipids. ${ }^{45}$ These antibodies seem to accelerate thrombosis in some patients-perhaps by their effects on the phospholipids of platelets or endothelial cell membranes. The risk of thrombosis is strong-indeed, for some patients with high antibody titres the risk ratio is higher than that for smoking. ${ }^{6}$

Although the antibodies are directed against various phospholipids, the early research selected cardiolipin as the test antigen-largely because reasonably pure cardiolipin was readily available. ${ }^{2}$ Sensitive and reproducible enzyme linked immunosorbent assays (ELISA) currently make testing for cardiolipin antibody cheap and widely available, ${ }^{7}$ and the assays have largely replaced older cumbersome "coagulation" tests such as the lupus anticoagulant test.

The original observations were made in systemic lupus erythematosus, a disease in which patients have a broad range of antibodies. Some patients with atypical systemic lupus erythematosus (who often failed to meet the classification criteria of the American Rheumatism Association) had recurrent thrombosis and recurrent abortion, and their serum contained phospholipid antibodies often without other autoantibodies. Later it became clear that most patients with this syndrome have little or no other evidence of lupus. The anticardiolipin syndrome-or more correctly the phospholipid antibody syndrome-is now reasonably well defined. ${ }^{3}$
The classic example of a patient with the syndrome is a young woman with a history of recurrent deep vein thrombosis, sometimes associated with the contraceptive pill or with stopping warfarin who then presents with recurrent spontaneous miscarriages. ${ }^{89}$ Other thrombotic events may include axillary, ocular, or renal vein thrombosis and the Budd-Chiari syndrome. ${ }^{10}$ "Several patients with the syndrome develop pulmonary hypertension, ${ }^{12}$ possibly because of episodes of pulmonary thrombosis. Major arterial thrombosis may also occur, especially recurrent strokes, ${ }^{13}$ early myocardial infarction, ${ }^{14}$ is and peripheral arterial occlusion. ${ }^{16}$ Several patients have developed multi-infarct dementia in association with phospholipid antibodies. ${ }^{17}$ Pregnant patients with raised titres of phospholipid antibodies (including the lupus anticoagulant) suffer a high risk of spontaneous abortion, possibly because of placental vessel thrombosis. ${ }^{1819}$ Indeed, some patients have had 10 or more failed pregnancies. Other features of the syndrome include livedo reticularis, ${ }^{20}$ chorea, ${ }^{21}$ and thrombocytopenia, ${ }^{22}$ and some speculate that the antibodies may be associated with disease of the heart valves, ${ }^{23}$ migraine and labile hypertension, ${ }^{20}$ and some myelopathies. ${ }^{24}$

There is a danger of overinterpreting the results of tests for phospholipid antibodies, especially those that give borderline results. It would not be surprising, for example, to find transient rises of antibody titre after certain infections. For this reason attempts to standardise the tests are important. ${ }^{25}$ The reliability of assays will be especially important in epidemiology: the true extent of the anticardiolipin syndrome is unknown, and large studies are in progress in vascular, 
cardiology, haematology, neurology, and rheumatology clinics as well as in obstetrics.

Treatment depends on careful anticoagulation, but the value of steroids, immunosuppressive agents, and plasma exchange is still not clear. In obstetrics, although claims of therapeutic success with various anticoagulation or immunosuppressive regimens increase each year, the data remain anecdotal and the overall results poor.

GRAHAM R V HUGHES

Consultant Rheumatologist,

Lupus Arthritis Research Unit,

Rayne Institute,

St Thomas's Hospital,

London SE1 7EH

1 Hughes GRV. Thrombosis, abortion, cerebral disease, and the lupus anticoagulant. Br Med $\mathcal{f}$ 1983;287:1088-9.

2 Harris EN, Gharavi AE, Boey $M$, et al. Anticardiolipin antibodies: detection by radioimmunoassay and association with thrombosis in systemic lupus erythematosus. Lancet 1983;ii:1211-4.

3 Hughes (GRV, Harris EN, Gharavi AE. The anticardiolipin syndrome. I Rheumatol 1986;13:486-9.

4 Khamashta MA, Harris EN, Gharavi AE, Morillas L, Hughes GRV. Towards an antibody mediated mechanism for thrombosis. Arthritis Rheum 1987;30:553.

5 Carreras LO, Vermylen J, Spitz B, Van Assche A. "Lupus" anticoagulant and inhibition of prostacyclin formation in patients with repeated abortion, intrauterine growth retardation and intrauterine death. Br f Obstet Gynaecol 1981;88:890-4.

6 Harris EN, Chan JKH, Asherson RA, Aber VR, Gharavi AE, Hughes GRV. Thrombosis, recurrent fetal loss, and thrombocytopenia: predictive value of the anticardiolipin antibody test. Arch Intern Med 1986;146:2153-6.

7 Gharavi AE, Hrris EN, Asherson RA, Hughes GRV. Anticardiolipin antibodies: isotype distribution and phospholipid specificity. Ann Rheum Dis 1987:46:1-6.
8 Asherson RA, Harris EN, Gharavi AE, Hughes GRV. Systemic lupus erythematosus, antiphospholipid antibodies, chorea, and oral contraceptives. Arthritis Rheum 1986;29:1535-6.

Asherson RA, Chan JKH, Harris EN, Gharavi AE, Hughes GRV. Anticardiolipin antibody, recurrent thrombosis, and warfarin withdrawal. Ann Rheum Dis 1985;44:823-5.

10 Asherson RA, Lanham J, Hull RG, Boey ML, Gharavi AE, Hughes GRV. Renal vein thrombosis in systemic lupus erythematosus: association with the "lupus anticoagulant." Clin Exp Rheumatol 1984:2:75-9.

11 Hughes GRV, Mackworth-Young CG, Harris EN, Gharavi AE. Veno-occlusive disease in systemic lupus erythematosus: possible association with anticardiolipin antibodies? Arthritis Rheum 1984;27:1071.

12 Asherson RA, Mackworth-Young C, Boey ML, et al. Pulmonary hypertension in systemic lupus erythematosus. Br Med f 1983;287:1024-5.

13 Harris EN, Gharavi AE, Asherson RA, Boey ML, Hughes GRV. Cerebral infarction in systemic lupus: association with anticardiolipin antibodies. Clin Exp Rheumatol 1984;2:47-51.

14 Asherson RA, Mackay IR, Harris EN. Myocardial infarction in a young male with systemic lupus erythematosus, deep vein thrombosis, and antibodies to phospholipid. Br Heart 7 1986;56:190-3.

15 Hamsten A, Norberg R, Bjorkolm M. Antibodies to cardiolipin in survivors of myocardial infarction: an association with recurrent cardiovascular events. Lancet 1986;i:113-5.

16 Asherson RA, Derksen RH, Harris EN, et al. Large vessel occlusion and gangrene in systemic lupus erythematosus and "lupus-like" disease. A report of 6 cases. I Rheumatol 1986;13:740-7.

17 Asherson RA, Mercey D, Phillips G, et al. Recurrent stroke and multi-infarct dementia in systemic lupus erythematosus: association with antiphospholipid antibodies. Ann Rheum Dis 1987;46: 603-11.

18 Derue GJ, Englert HJ, Harris EN, et al. Fetal loss in systemic lupus: association with anticardiolipin antibodies. 7 Obstet Gynaecol 1985;5:207-9.

19 Lockshin MD, Druzin ML, Goei S, et al. Antibody to cardiolipin as a predictor of fetal distress or death in pregnant patients with systemic lupus erythematosus. N Engl f Med 1985;313:152-6.

Heath in pregnant patients with systemic lupus erythematosus. N Engl f Med 1985;313:15

21 Asherson RA, Derksen RH, Harris EN, et al. Chorea in systemic lupus erythematosus and "lupus-like" disease: association with antiphospholipid antibodies. Semin Arthritis Rheum 1987; 16:253-9.

22 Harris EN, Asherson RA, Gharavi AE, Morgan SH, Derue G, Hughes GRV. Thrombocytopenia in SLE and related autoimmune disorders: association with anticardiolipin antibody. Br f Haematol 1985;59:227-30

23 Asherson RA, Lubbe W. Heart valve disease and antiphospholipid antibodies. I Rheumatol 1988; 15:539-43.

24 Harris EN, Englert H, Derue G, Hughes GRV, Gharavi A. Antiphospholipid antibodies in acute Guillain-Barré syndrome. Lancet 1983;ii:1361-2.

25 Harris EN, Gharavi AE, Patel S, Hughes GRV. Evaluation of the anticardiolipin antibody test: report of a standardisation workshop held April 4, 1986. Clin Exp Immunol 1987;68:215-22.

\section{Hyperprolactinaemia}

\section{Common and treatable}

Hyperprolactinaemia is the underlying cause in almost $15 \%$ of women who do not ovulate ${ }^{1}$ and usually results from tumours producing prolactin (prolactinomas), the commonest type of pituitary tumour. ${ }^{2}$ Indeed, one necropsy study of unselected patients showed that more than one in 10 had a prolactinoma ${ }^{3}$; most had presumably been without symptoms. Conversely, mass screening of 10550 normal adults in Japan found only five who were considered to have a prolactinoma. ${ }^{4}$

The diagnosis of hyperprolactinaemia must be based on more than one measurement. Although the upper limit of the normal range is often quoted as $360 \mathrm{mU} / \mathrm{l}$, it really extends to $700-800 \mathrm{mU} / \mathrm{l}$ because of the skewed normal distribution. ${ }^{56}$ Even concentrations above this do not necessarily indicate the clinically important hyperprolactinaemia that suppresses pulsatile secretion of gonadotrophin releasing hormone from the hypothalamus leading to secondary gonadal failure. ${ }^{7}$

In women prolactin concentrations up to $1000 \mathrm{mU} / \mathrm{l}$ are associated with a low incidence of menstrual irregularity and no response to treatment with bromocriptine. ${ }^{89}$ Even higher concentrations are unlikely to be clinically important in a woman who is menstruating normally, ${ }^{10}$ and they do not usually require investigation. The discrepancy between clinical and biochemical findings may sometimes be caused by measurement of biologically inactive but immunologically reactive hormone. ${ }^{11}$

Once pregnancy, the effect of drugs, and hypothyroidism have been excluded the most likely cause of hyperprolactinaemia is a prolactinoma. Other pituitary lesions must, however, be kept in mind. Thus non-functioning pituitary tumours may cause hyperprolactinaemia by interfering with normal hypothalamic inhibition of prolactin secretion. These tumours usually do not respond to medical treatment. The hyperprolactinaemia in patients with such lesions is commonly only mild — up to $3000 \mathrm{mU} / \mathrm{1}^{12}{ }^{13}$ —although it may occasionally be as high as $8000 \mathrm{mU} / \mathrm{l}$; a plain radiograph of the pituitary fossa usually shows abnormal results. In contrast, prolactinomas may cause any degree of hyperprolactinaemia. Those associated with mild hyperprolactinaemia are usually so small (microadenomas) that they only rarely distort a plain radiograph of the pituitary. Patients with an abnormal pituitary fossa in a plain radiograph should have their visual fields checked and have computed tomography. Computed tomography is not usually necessary in those with normal results in plain films of the pituitary (unless an operation is contemplated) as the examination is unlikely to affect management, is costly, and may be misleading, even with high resolution scans. ${ }^{14}$ is If, however, there are any clinical features in addition to hyperprolactinaemia that suggest a pituitary lesion computed tomography may be needed.

Clinically important prolactinomas are much more common in women than men, which has been attributed to an effect of oestrogen, although this remains uncertain. ${ }^{16}$ The usual presentation of hyperprolactinaemia is amenorrhoea and associated infertility and symptoms of oestrogen deficiency; galactorrhoea occurs in about one third of patients. Many women with galactorrhoea do not, however, have hyperprolactinaemia ${ }^{17}$ : the condition probably arises from the abnormal sensitivity of breast tissue to normal serum concentrations of prolactin. ${ }^{18}$ Such women do not require further investigation of the pituitary, but if the galactorrhoea is sufficiently embarrassing to warrant treatment it usually responds to suppression of prolactin with a dopamine agonist. In men hyperprolactinaemia may cause loss of libido and impotence, although it accounts for these common symptoms only rarely.

Hyperprolactinaemia nearly always responds to treatment with a dopamine agonist, which may reduce the size of an underlying prolactinoma. ${ }^{19}$ Bromocriptine is used most often, 